\title{
Sexuality-based Stigma and Inclusion Among Southern Protestant Religious Leaders
}

\author{
Elizabeth A. Mosley ${ }^{1,2}$ (D) S Subasri Narasimhan² $\cdot$ John Blevins ${ }^{2} \cdot$ Jessica L. Dozier ${ }^{2} \cdot$ Johanna Pringle $^{2} \cdot$ Lasha S. Clarke $^{2}$. \\ Cherisse Scott ${ }^{3} \cdot$ Mary Kan $^{2} \cdot$ Kelli Stidham Hall ${ }^{2}$. Whitney S. Rice ${ }^{2}$
}

Accepted: 21 October 2021 / Published online: 9 November 2021

(c) The Author(s) 2021

\begin{abstract}
Introduction Sexuality-based stigma is prevalent in the USA and is, in part, based on religious and gender norms. In the South-compared to other regions-religiosity is more salient, gender norms are more conservative, and sexual and reproductive health $(\mathrm{SRH})$ inequities are more prevalent.

Methods Guided by a stakeholder Advisory Committee, the researchers conducted 20 in-depth interviews with Protestant religious leaders in Georgia from 2018 to 2019 to explore how faith leaders describe sexuality-based stigma, including toward abortion and sexual and gender minorities. Interviews were transcribed and thematically analyzed using team-based, iterative coding.

Results Religious leaders held a wide range of abortion and sexuality attitudes and norms. Some described traditional judgment around the "sins" of abortion, "homosexuality," and/or "transgender people" based on Scripture and constructs of the cisgender binary and sexual purity. But the researchers noted tension between that judgment and Christian ideologies of "love" and "all people [being] welcomed...[no] matter who you are." Several participants provided counter-examples for building supportive and empathic abortion and sexuality norms—including LGBTQ inclusivity—through de-stigmatizing testimony and personal relationships.

Conclusions There are linkages between abortion stigma and stigma against sexual/gender minorities among Southern religious leaders. However, there is also support for abortion and LGBTQ inclusivity. We assert that assets-based engagement of religious leaders is critical for building effective, inclusive faith-based SRH programming.

Policy Implications These findings demonstrate the need for national, state, and local policies that protect comprehensive sex education, abortion access, and LGBTQ people.
\end{abstract}

Keywords Abortion $\cdot$ Religion $\cdot$ Stigma $\cdot$ Sexual minority $\cdot$ Gender minority $\cdot$ Reproductive health

\section{Introduction}

Public health, sociology, and psychology scholars describe stigma as a dynamic, discrediting, and multi-level social process that ascribes negative characteristics to and discriminates

Elizabeth A. Mosley

emosley@gsu.edu

1 Georgia State University School of Public Health, Mark Chaffin Center for Healthy Development, P.O. Box 3995, Atlanta, GA 30302-3995, USA

2 Emory University Rollins School of Public Health, Center for Reproductive Health Research in the Southeast, Atlanta, GA, USA

3 SisterReach, Memphis, USA against those associated with a non-normative attribute or behavior (Goffman, 1963; Hatzenbuehler et al., 2013; Link \& Phelan, 2001; Norris et al., 2011). Some common examples are stigma against certain sexual and reproductive health topics, including abortion (Cockrill et al., 2013; Frohwirth et al., 2018; Norris et al., 2011) and unintended pregnancy (Rice et al., 2017), and stigma against sexual and gender minority groups (Graham, 2014; Herek et al., 2007; Meyer, 1995; White Hughto et al., 2015) such as lesbian, gay, bisexual, transgender, and queer (LGBTQ) people. Stigma against having an unintended pregnancy or abortion may lead to isolation (Cockrill et al., 2013; Rice et al., 2017), reproductive coercion (Rice et al., 2017), self-managed and unsafe abortion (Harris, 2012), restrictive policies against abortion (Kumar et al., 2009; Norris et al., 2011), conflict with 
partners and family members (Cockrill \& Nack, 2013; Smith et al., 2016), and rejection of religious identity or affiliation (Frohwirth et al., 2018). Stigma against gender and sexual minorities can lead to mental health distress and suicidality (Graham, 2014; Herek et al., 2007; Meyer, 1995), economic vulnerability (Herek et al., 2007; White Hughto et al., 2015), violence (Herek et al., 2007; Meyer, 1995; White Hughto et al., 2015), and HIV transmission (Graham, 2014; Herek et al., 2007; White Hughto et al., 2015) among other health consequences. Further, different forms of stigma can be compounded, a phenomenon known as intersectional stigma, especially for groups with multiple marginalized identities and experiences (Earnshaw \& Kalichman, 2013).

Religious affiliation and involvement can be highly protective of physical and mental health, but religiosity can actually be detrimental for groups who experience faith-based stigma (White et al., 2019). Faith-based stigma refers to a stigma process that originates in religious doctrine, practices, and beliefs by marking attributes or behaviors as immoral or unholy (Goodman, 2017; Krawczyk et al., 2006; Päivänsalo, 2013). Both reproductive health stigma and gender/sexual minority stigma are rooted, in part, in religiously-based attitudes and community norms (Frohwirth et al., 2018; Gaydos et al., 2010; Kumar et al., 2009; Smith et al., 2016; White Hughto et al., 2015). This is because religiosity and stigma against abortion, unintended pregnancy, and gender/sexual minorities are inherently intertwined with gender norms and expectations of sexual purity (Herek et al., 2007; Jelen, 2015; Kumar et al., 2009; Mosley et al., 2019; White Hughto et al., 2015). Abortion conflicts with traditional Christian expectations of the "good woman" as characterized by (1) compulsory motherhood and (2) sexual purity except within procreative marriage (Kumar et al., 2009; Norris et al., 2011, p. 6). Stigma against LGBTQ identities and behaviors stems from heterosexism and homophobia in many Christian institutions and communities, which often condemn homosexual behavior as sinful (Herek et al., 2007). Notably, the Christian condemnation of homosexuality was one aspect of a larger prohibition against all non-procreative sexual acts including extramarital sex, masturbation, and (the researchers would argue) abortionall of which were labeled as "unnatural sins against nature" (Herek et al., 2007). Therefore, to the extent that abortion and LGBTQ people disrupt hegemonic cisgender ${ }^{1}$ norms (including expectations that women are meant to be nurturing mothers and that gender is biologically determined) and myths of sexual purity (that sex is meant only for procreation between married men and women), they threaten dominant Christian

\footnotetext{
${ }^{1}$ Cisgender, from the Latin cis meaning on this side of, is the opposite of transgender. Cisgender people identify with and express the same gender and sex they were assigned at birth (e.g., women who were born female and men who were born male).
}

religious doctrine and community norms (Herek et al., 2007; Kumar et al., 2009; White Hughto et al., 2015).

In general, individuals who identify as Protestant ${ }^{2}$ and those who are more religious (e.g., attend religious events more frequently, pray more often, hold fundamentalist beliefs) have more negative attitudes toward abortion (Jelen \& Wilcox, 2003; Mosley et al., 2019; Rice et al., 2017) and same-sex relations (Herek et al., 2007) as well as greater experiences of abortion stigma (Cockrill et al., 2013; Cockrill \& Nack, 2013) and gender/sexual minority stigma (Szymanski \& Carretta, 2020). At the same time, the sexual and reproductive beliefs, attitudes, and social norms of religious leaders and congregations are highly diverse and complex (Dozier et al., 2020; Jeffries et al., 2008; Lindley et al., 2010). For example, according to a national Pew Research Center survey, 57\% of (Historically-Black Protestant) National Baptist congregants believe abortion should be legal in most cases compared to 79\% of Episcopal Church congregants or $30 \%$ of (Evangelical) Southern Baptist congregants (Masci, 2018). Notably, the prohibition against non-procreative sexual acts remained in force until the middle decades of the twentieth century, when some Protestant Christian denominations in the United States articulated positions in support of birth control and abortion access; prohibitions against homosexuality have been slower to change, although many mainline Protestant denominations now affirm loving sexual expression among LGBTQ people (Blevins, 2018, pp. 64-66, 112, 158). Today, 53\% of Black Protestants report that same-sex marriage is "very bad" or "somewhat" bad for society compared to $36 \%$ of nonEvangelical Whites and 72\% of White Evangelical Protestants (Pew Research Center, 2019).

Stigma against abortion, unintended pregnancy, and gender/sexual minorities is especially pervasive in the US South, where Christianity is especially salient (Dillon \& Savage, 2006; Rice et al., 2017; Smith et al., 2016). For one, structural stigma is more prevalent in the South, including harmful policies that restrict abortion care (Nash, 2019), lack of protection for LGBTQ parents (Hasenbush et al., 2014), and policies that obstruct access to gender-affirming healthcare (Movement Advanced Project, 2021). Americans living in the South, particularly rural areas, are also more likely to hold negative attitudes against both abortion and same-sex relations (Dillon \& Savage, 2006). This is attributed, in part, to the greater proportion of Southerners who

\footnotetext{
2 Notably, these empirical findings about "Protestant" abortion attitudes and stigma come from the General Social Survey, a nationallevel survey in the United States, and the World Values Survey, which includes national-level data from over 50 countries. They include a wide range of denominations under the large umbrella of Protestantism, with some denominations holding more conservative stances on abortion than other denominations.
} 
identify as Christian and to the greater levels of religiosity and fundamentalism (Dillon \& Savage, 2006). At the same time, and perhaps in part because of high religiosity, Southern sexual and reproductive health outcomes and inequities are worse compared to other US regions. In the South, there is greater burden of unintended pregnancy (Rice et al., 2017), self-managed abortion (Jones et al., 2019), and HIV/ AIDS (Reif et al., 2014)—each of which disproportionately affect people of color and youth of color.

Faith-based health interventions are a promising avenue for reducing faith-based stigma and its health consequencesespecially because they could reach the $51 \%$ of Americans who attend religious gatherings regularly (National Opinion Research Center, 2021) and can leverage the perceived trustworthiness of religious leaders (Griffith et al., 2010)—but programs focused on sexual and reproductive health are rare and typically developed only for Black churches. Religion and spirituality are particularly important for Black Americans, as more Black Americans report absolute or certain belief in God compared to other racial/ethnic groups (Pew Research Center, 2020a). Black churches have been essential sites for community-building, social support, spiritual healing, and political activism in the face of racism and racialized violence (Jeffries et al., 2008; Pingel \& Bauermeister, 2018; Powell et al., 2016; White et al., 2019), and faith community participation is associated with physical and mental health benefits that can reduce racial/ethnic health disparities (White et al., 2019). In turn, Black churches have become important locations for community-based health promotion for a wide range of outcomes from cancer to HIV across the USA and in the South, specifically (Bradley et al., 2018; Griffith et al., 2010; Jeffries et al., 2008; Lindley et al., 2010; Pingel \& Bauermeister, 2018; Powell et al., 2016; White et al., 2019). However, research focused on church-based HIV programs with Black LGBTQ community members has highlighted important challenges including homophobic religion-based norms among clergy and congregants as well as HIV and other sexual health-related stigma (Bradley et al., 2018; Jeffries et al., 2008; Lindley et al., 2010; Powell et al., 2016; White et al., 2019). Notably, these programs have not addressed sexual and reproductive health comprehensively to include unintended pregnancy, abortion, and LGBTQ health broadly. Yet sexual and reproductive health interventions are particularly needed in highly religious contexts like the South, where public sex education is limited and not evidence-based (Guttmacher Institute, 2020).

Religion and sexual and reproductive health is a growing field of scholarship, but many gaps remain and experts have called for more qualitative research, in particular (Gaydos et al., 2010). For this manuscript, the researchers use qualitative data from a larger religion and reproductive health project (Dozier et al., 2020) to explore this central research question: how do faith leaders describe sexuality-based stigma, including toward abortion and sexual and gender minorities? More specifically, the team investigated (1) differences between White and Black Protestants' attitudes toward abortion and sexual and gender minorities; (2) church practices (e.g., pastoral care, programming) around abortion, gender minorities, and sexuality; and (3) implications for church-based health programming around abortion and sexual and gender minorities.

\section{Methodology}

The Engaging Faith Communities in Georgia (EnFaith) is a stakeholder-engaged, mixed methods project to promote supportive sexual and reproductive health attitudes and norms in mainline and Black Protestant churches (Dozier et al., 2020). Primary aims of the EnFaith project are to inform evidence-based intervention development, to measure sociocultural norms (including stigma) of sexual and reproductive health in religious communities, and to identify current faith-based practices related to sexual and reproductive health including pastoral care. The study is grounded in a multi-level conceptual model that primarily draws from the Theory of Triadic Influence (Flay et al., 2009) (intrapersonal, social situation, and culture), Moral Foundations Theory (Graham et al., 2013), and stigma (Hatzenbuehler et al., 2013) and intersectionality (Crenshaw, 1989; Mullings \& Schulz, 2006) frameworks. EnFaith is located in a Georgia county ${ }^{3}$ with high abortion rates (Georgia Department of Public Health, 2020), low access to abortion (National Abortion Federation, 2020), high religiosity and denominational diversity (Association of Religion Data Archives, 2010), demographic diversity (United States Census Bureau, 2020), and an urban center with surrounding suburban and rural areas. The EnFaith Advisory Committee (EAC) is a stakeholder group comprised of Protestant clergy, reproductive rights and justice advocates, theologians, and non-profit organizations that provide sexual and reproductive health education and support to churches within the USA. The EAC guides the project team through research development (e.g., selecting study site, creating interview guides, developing a sampling and recruitment strategy) and execution (e.g., assistance with recruitment, review of findings, support with dissemination of findings). All research activities have been approved by the Emory University (IRB IRB00106069).

Data collection and analysis was conducted by a team of 10 racially, ethnically, and religiously diverse researchers, who did not have any relationship with the respondents. The team included doctoral-level and Master's-level qualitative

\footnotetext{
$\overline{3}$ The county and references have been kept anonymous for participant confidentiality.
} 
researchers, who provided scaffolded instruction, classroom practice, and mentored fieldwork to graduate and undergraduate students on the team. Trainings included qualitative paradigms (positivism vs. interpretivism), qualitative data sources, fieldnotes, observation, interviewing techniques, memo-ing, coding, and qualitative software. The researchers completed 20 in-depth, semi-structured interviews with religious leaders including Senior Pastors, Youth Pastors, and lay leaders (i.e., non-clergy congregants chosen for leadership roles within the church) from October 2018 to September 2019. The researchers intentionally stratified the sample by mainline and Black churches in order to ensure a racially diverse sample, given the important differences in religious experiences and health outcomes by race noted above. Purposive sampling was utilized to recruit a sample of religious leaders from mainline and Black Protestant churches. These churches were identified using a publicly available list of churches by county published by The Association of Religious Data Archives. The names and contact information for the primary religious leader of the identified churches were extracted from church websites and social media accounts. Snowball sampling and social media messaging were employed to recruit lay leaders since their contact information was not as publicly available. Additionally, leaders were approached in person and recruited at centers of commerce within the county. Participants were asked about the sexual and reproductive health priorities of their church; their views on sexual activity, unintended pregnancy, and abortion; their current practices of pastoral care; and their recommendations for church-based sexual and reproductive health programs. Participants were not explicitly asked about LGBTQ-related topics, but if the participant discussed (i.e., more than mentioned in passing) homosexuality or LGBTQ people, they were further probed about how their views had changed over time and how they responded in their pastoral duties (e.g., to gay families in church). These interviews, which lasted between 45 and 90 min, were recorded, transcribed, and de-identified; participants were given a $\$ 50$ gift card for their time.

The research team developed a codebook through iterative team-based reviewing and memo-ing, and applied that codebook across all transcripts using Dedoose (Dedoose, 2018). Inductive and deductive strategies were applied to develop the codes. Consistency in the coding process was ensured by an inter-coder agreement exercise, which was conducted before coding the entire data. Weekly team meetings were also employed to redefine code definitions when needed and resolve inconsistencies in coding. Using the developed codebook, thematic analysis was utilized to describe the religious leaders' attitudes and beliefs toward the various interview topics. Although questions about gender and sexual minorities were not specifically included on the interview guide, the researchers intentionally used gender inclusive and non-heteronormative language, and many religious leaders organically discussed LGBTQ-related topics, which the researchers then probed for in more detail. Notably, the full codebook and interview guide can be found as appendices in an earlier manuscript from the larger study (Dozier et al., 2020). This current manuscript focuses on the codes "LGBTQ" and "abortion" with other co-occurring codes including but not limited to church norms, attitudes and beliefs, scripture, gender, pastoral care, marriage, sin, psychosocial effects, and social inclusion. Themes were developed using thematic analysis techniques such as memo-ing, group comparisons, code matrices, and diagramming.

\section{Results}

\section{Demographics}

The sample of 20 religious leaders was diverse across numerous demographic characteristics including gender, race, political affiliation, age, education level, role in the church, denomination, urbanicity, and congregation size (see Table 1). The sample was $80 \%$ men and $20 \%$ women; this reflects the current national distribution of clergy members by gender ( $82 \%$ male, $18 \%$ female) (Woolever et al., 2020). It was also 50\% Black and 50\% White (due to stratification) and 65\% Democrat, 20\% Independent, and 15\% Republican. This accurately reflects political distribution in the state of Georgia by race: $73 \%$ of Black adults and $25 \%$ of White adults identify as Democrat, $12 \%$ Black adults and 59\% of White adults identify as Republican, and $15 \%$ of Black adults and $17 \%$ of White adults identify as moderate or independent (Pew Research Center, 2020b). The average age of the sample was 48 years (range, 26-72), and while the majority of participants had a masters-level graduate degree $(65 \%)$, others had an Associate's (5\%), 4-year college (25\%), or doctoral (5\%) degree. Roles within the church also varied: most participants were Senior Pastors (60\%), but the researchers also interviewed associate ministers and pastors (10\%), lay leaders and ushers (10\%), and a Regional Minister (5\%), an Associate Pastor (5\%), and a First Lady (5\%). Baptist churches were the most common denomination in the sample (30\%), which included National Baptist churches (10\%), Black Southern Baptist churches (10\%), a National Missionary Baptist church (5\%), and an unspecified Baptist church (5\%), followed by United Methodist (25\%), and African Methodist Episcopal churches (10\%). Considering that we excluded Evangelical congregations and stratified by Black and Mainline churches, this sample distribution is similar to the population in this Georgia County by church denomination (Association of Religion Data Archives, 2010). Over half (55\%) of the churches were in urban areas, and $40 \%$ were in suburban areas. Most were mid-to-large congregations of 251-1000 members (50\%) or 101-250 members (30\%), while 1 church 
Table 1 Characteristics of religious leaders and churches included in the study sample

\begin{tabular}{|c|c|c|c|c|c|}
\hline Participants Characteristic & $\mathbf{n}$ & $\%$ & Church Characteristic & $\mathbf{n}$ & $\%$ \\
\hline Gender & & & Denomination & & \\
\hline Man & 16 & $80 \%$ & Baptist & 6 & $30 \%$ \\
\hline Woman & 4 & $20 \%$ & United Methodist Church & 5 & $25 \%$ \\
\hline Race & & & African Methodist Episcopal & 2 & $10 \%$ \\
\hline Black & 10 & $50 \%$ & Episcopal & 1 & $5 \%$ \\
\hline White & 10 & $50 \%$ & Lutheran & 1 & $5 \%$ \\
\hline Educational Level & & & Disciples of Christ & 1 & $5 \%$ \\
\hline Associate's Degree & 1 & $5 \%$ & Pentecostal & 1 & $5 \%$ \\
\hline Completed (4-Year) College & 5 & $25 \%$ & Non-denominational & 1 & $5 \%$ \\
\hline Graduate Degree & 13 & $65 \%$ & Presbyterian & 1 & $5 \%$ \\
\hline Doctorate & 1 & $5 \%$ & Congregational Methodist Church & 1 & $5 \%$ \\
\hline Role & & & Urbanicity & & \\
\hline Senior Pastor & 12 & $60 \%$ & Urban & 11 & $55 \%$ \\
\hline Minister/Pastor & 2 & $10 \%$ & Suburban & 8 & $40 \%$ \\
\hline Lay Leader/Usher/Support & 2 & $10 \%$ & Unknown & 1 & $5 \%$ \\
\hline Regional Minister & 1 & $5 \%$ & Congregation Size & & \\
\hline Associate Pastor & 1 & $5 \%$ & Fewer than 50 people & 2 & $10 \%$ \\
\hline Youth Minister & 1 & $5 \%$ & 51-100 people & 1 & $5 \%$ \\
\hline First Lady & 1 & $5 \%$ & 101-250 people & 6 & $30 \%$ \\
\hline Political Affiliation & & & 251-1000 people & 10 & $50 \%$ \\
\hline Democrat & 13 & $65 \%$ & More than 1000 people & 1 & $5 \%$ \\
\hline Independent & 4 & $20 \%$ & & & \\
\hline Republican & 3 & $15 \%$ & & & \\
\hline \multicolumn{6}{|l|}{ Age } \\
\hline Average & 48 & -- & & & \\
\hline Maximum & 72 & -- & & & \\
\hline Minimum & 26 & -- & & & \\
\hline
\end{tabular}

had a congregation of over 1000 people $(5 \%)$ and 3 churches had 100 or fewer members $(15 \%)$.

\section{Overview}

From the interviews, the researchers identified one major theme situated at the intersection of abortion stigma and gender and sexual minority stigma: faith-based judgment around abortion and LGBTQ identities and behaviors are similarly rooted in prescribed gender roles and sexual purity norms. This was supported by subthemes: (a) tension exists between that judgment and Christian ideologies of love and acceptance, (b) there are examples of non-judgment and inclusion of people who have had an abortion and LGBTQ people, and (c) common strategies can be utilized for shifting churchbased abortion and LGBTQ norms toward support, empathy, and love. Findings highlighted the diversity of views and actions surrounding abortion and sexual/gender minorities ranging from full endorsement of doctrine-based stigma to full endorsement of church-based comprehensive sexuality education. All 20 participants discussed attitudes, norms, and practices around abortion, unplanned pregnancy, and sexuality in response to the questions about pastoral care, personal attitudes and beliefs, and congregational responses to abortion and unplanned pregnancy. Ten of the religious leaders specifically and organically mentioned LGBTQ identities or behaviors in response to general questions about sexual and reproductive health without being prompted. The other ten religious leaders did not specifically mention LGBTQ identities or behaviors. Three religious leaders shared examples of existing formal programming on sexual and reproductive health or LGBTQ topics (one panel on transgender people, one youth group covering pregnancyrelated questions, and one abstinence-only youth program), while all leaders shared examples of how they informally address these topics through pastoral care, sermons, and informal culture in the community.

\section{Shared Religious Roots of Abortion and Gender/ Sexual Minority Stigma}

Participants described how abortion stigma and stigma against gender/sexual minorities in Protestant communities stem from common dogmatic roots (including Scripture and 
community gender norms) and how they similarly manifest in pastoral counseling, sermons, and other leadership duties. First, when discussing abortion, many religious leaders invoked "homosexuality" and "being transgender" as similar examples of sinful transgression against traditional faith-based social norms of gender roles and sexual puritywhether or not they actually agreed with those traditions. While religious leaders commonly evoked "You shall not murder" (Exodus 20:13 NSRV) as a Biblical reference that applies to abortion, they also alluded to Scripture ${ }^{4}$ on gender roles, procreation, and sexuality. This included "Wives, be subject to your own husbands, as you are to the Lord. For the husband is the head of the wife just as Christ is the head of the church" (Ephesians 5:22-23, NRSV), "Children are a gift from the LORD; they are a reward from Him," (Psalms 127:3, NLT), "Be fruitful and multiply," (Genesis 1:28, NSRV), and "If a man lies with a male as with a woman, both of them have committed an abomination; they shall be put to death; their blood is upon them." (Leviticus 20:13, NRSV).

The traditional church norms and Scripture that leaders described are based on the social construction of a cisgender binary, meaning there are two genders (men and women) that align with two distinct sexes (male and female) that have separate social roles based on those categories. Adherents to these norms understand them to be complementary, and they offer a complete model of God's intention for family and social structures (Ward, 1998). Participants explained how this cisgender binary dictates appropriate behaviors for women and men around sex and sexuality and, in turn, defines and condemns inappropriate or taboo identities or behaviors such as sex before or outside of marital union, abortion, being transgender, and "homosexuality." One Black female youth minister (P14) tied abortion, sanctity of life, and sexual purity together when she described her hypothetical pastoral counseling of a congregant, who was considering abortion:

I'll let them know, like "Hey, well you know abortion would be considered killing, so would you really want to kill a life?" Also to get them to see that what if the child that you are carrying, God has a mission for them that can change the world. Because when Jesus was born, he came through the Virgin Mary. And she was getting ready to get married to Joseph and people wanted to stone her. But it was just like she had to sit there and endure all that... the sin was in the act of

\footnotetext{
${ }^{4}$ In general, the researchers have used the New Revised Standard Version for Biblical references, except when study participants explicitly quoted from other translations such as the New Living Translation.
}

sex, but the sin isn't what's growing on the inside... In the Bible, God puts it plain and simple that sex is for people that are married...if you're unmarried and you have sex, then of course, it's a sin, but does that sin separate you from the love of God?

In her response, it was evident this pastor adheres to a dogmatic view of abortion, marriage, sex, and gender roles that manifests in her pastoral counseling. In contrast, a White male lay leader (P20) described similar elements of the cisgender binary he encountered in his childhood church although he no longer subscribes to those views,

That was a brainwashed type of theology that was placed in me at a very young age by the constructs of a church that I was a part of. It was very rigid, very anti - oh gosh, anti-gay, anti-abortion, anti-women, pretty much. Like, women didn't speak in the church. Women didn't have a role in the church. All the men were deacons. Women taught Sunday School and that was it. They kept the nursery. They cooked casseroles on Sunday afternoon for the - you know, that was a role of a woman in the church.

According to our participants, transgressive sexual behaviors (like abortion and premarital sex) and transgressive sexual identities fell under an umbrella of sexuality-based sin. Many religious leaders saw abortion and "homosexuality" as linked by concepts of sexuality-based sin, because they pervert God's intention of complementarity between men and women which, according to a minority of participants, includes sex solely for procreation between men and women. At times, religious leaders connected spiritual abnormalities (like distance from God or "emptiness") and/or the manifestation of "physical abnormalities" (like fetal or hormonal anomalies), when discussing outcomes of sexuality-based sin. When discussing abortion, a few pastors raised transgender individuals as examples of a similar departure from "normalcy." The language used by a few religious leaders to describe transgender people mirrored the language used to describe women who had abortions, and both were laden with stigma connected to the cisgender binary. One White male Pastor (P02) equated transgender and sexual minority individuals to a baby born with "physical and genetic abnormalities" because of sin saying,

I believe that some young ladies, some females, and some males... because of sin, the hormonal balance is out of whack. I believe...that there's some young boys that come out that's got a higher rate of female hormones in 'em... So that's why you get some young men that are more feminine, and then you get some young ladies that are more masculine...it's a result of the sin nature that we're born into... I get that you were born with these hormonal abnormalities, just like my grand- 
son, was born [out of wedlock] with these physical and genetic abnormalities...So God ... He said, "Listen. Be fruitful and multiply." He gave them the gift of sex to procreate... But when sin entered it, it corrupted it. The act of procreating is God-given. But tainted with sin, you get abnormalities in the birth.

Participants also described how, stemming from those common roots of the gender binary and sexuality purity, abortion, and gender/sexual minority stigma were similarly enacted in church practices including sermons, pastoral counseling, and church programs. One Black male Senior Pastor (P06) described public shaming for unintended pregnancy and other transgressions, "When I was growing up, church was crazy. You'd have to come back to the church and announce that you had messed up." The previous White male Pastor (P02) demonstrated how sexuality stigma is enacted during his counseling with people on homosexuality, abortion, and unintended pregnancy:

Like my [lesbian] sister. I said, "I've got my own urges that I battle... I would've been a fourth generation alcoholic, so I battle that urge with alcohol. But just because I was born with that taste... doesn't mean that, oh, I can just go on and go ahead and drink. I had to refrain from that urge to save my life, and save my family." So I tell my sister, "I understand the urges... It's a battle you got, because in this world, it's gonna be tough. The easiest thing for you to do is just give in and say, 'Hey, I'm a lesbian. I was born this way."' But her whole life she's fought and battled and struggled... Just fight the urge. Just fight the urge. [pastor lightly pounds on the desk] I've had to fight urges. And the urges I have are as a result of $\sin$ in the world, just like the urges you're fighting are because of $\sin$ in the world. You just can't give in to those.

Another White male Senior Pastor (P19) demonstrated how even inclusive churches still equate premarital sex and same-sex relations as sinful—albeit forgivable:

In the United Methodist Church, we say everybody is welcome... But the United Methodist Church has a particularly nuanced view of sexual expression as only viable within the confines of marriage...But we have folks who come faithfully who are living with partners, both heterosexual and homosexual, even though that goes against officially the teaching of the United Methodist Church...And we don't harp on it; we don't wanna make anyone feel ostracized because of one thing. I think it's much better to preach in nuanced kinda terms where people can apply things to themselves, instead of hearing a sermon and feeling bashed by it... on one of those sermons we hit on human sexuality and divorce... we talked about it in the way Jesus talked about it... Jesus said, "No, you're just as unrighteous as anybody else, so don't get up on a pedestal." So that's the kinda thing that I would say. And within that language then, everyone can hear equally the condemnation that Jesus clearly brings, that lust is incorrect for us as children of God, but grace is also available.

Participants also described how sexuality-based stigma creates silence and disconnection, wherein there is little to no programming on the topic and congregants do not share their sexual and reproductive health concerns with pastors, particularly if they are male. The White male Senior Pastor (P19) continued,

Someone would call, or stop me on a Sunday and say, "Can I come in and see you?" And they book an appointment, and come in and sit down, and tell me that they're struggling with infertility, which has happened very recently, or that they're pregnant and they don't really wanna be pregnant, that kinda thing. So it'd be much more prone to happen sitting in this room after either a phone call or a personal request for an appointment...They don't happen often, actually. And maybe it's because I'm a man, and we have two associate pastors on staff that are women... So I think that they might field more of these sorts of questions and concerns than I would.

A B+lack male Senior Pastor (P13) candidly shared,

Now, the challenge for me now, having this conversation, is to go ahead and bring it [sexuality] up. Go ahead and institute some type of dialogue, educational piece, so that we are fully aware of what our options are and what we're dealing with. So you're making me do something that I hadn't done.

\section{Subtheme: Tension Exists Between Judgment and Christian Ideologies of Love}

There is a clear tension or cognitive dissonance between leaders perceiving themselves loving LGBTQ people and people who have had an abortion, while describing homophobic or transphobic attitudes and stigmatizing beliefs about abortion. One White male pastor (P02) began by describing a utopian vision for his church,

I long for the day that I look across that parking lot and ...that a man and a man are coming in the door... A woman and woman coming in the door. A drug addict coming in the door...Alcoholic coming in the door. Transgender coming in the door...And the Bible says that where the spirit of God is, there's freedom... When that woman that's had that abortion - she may've had that abortion the day before. And guilt- 
ridden, ashamed - I want the word to be out in [this city] that you're welcome here.

But then he added,

Now, Jesus says, 'Come follow me, and I'll make you fishers of men.' He didn't say cleaners of men. He said, 'You catch 'em, I'll clean 'em.'

In contrast, one Black male Minister (P13) explicitly condemned the inauthentic, performative inclusion of other churches and called for real inclusivity based on love. He said,

I find myself amused when churches use or have "Welcome" at their door, because that's not true, and you need to take it down... because if two males came in holding hands, would they be welcome? If two females came in holding hands, would they be welcome? If someone came in looking to the church for resources for abortion, would that be welcoming? Is your focus to minister to the whole person, or is it your mission to drive your ideological view on what you believe the Deity stands for? And somewhere in the biblical text... is "God is love." So what the world needs now, sho' 'nuff, is love. More love, and more love on love.

\section{Subtheme: Examples of Inclusivity for LGBTQ or People Who Have Had an Abortion}

At the same time, it is important to note that most faith leaders gave examples of non-judgment, inclusivity, and support for people who are LGBTQ or who have had an abortion. Several faith leaders described LGBTQ liberation activities happening in Southern Protestant churches including trans inclusion, reconciling ministries, and explicit affirmation of LGBTQ communities. Several religious leaders denounced "crazy biblical views of sexuality" including the promotion of violence against gay people and others who are "different." One White male lay leader (P20) explained his church now "does pronouns" and is moving away from "genderspecific" activities, because they "have transgender people that go to church with us" and gender-specific activities "leav[e] out a group of people that may not identify with either [gender]." He went on to explain,

I am the coordinator for reconciling ministries at my church... we make intentional spaces where conversations can happen...we had a panel that had a transgender person on it, [and] someone who was raised in the church that now identifies as a gay man. And we had them tell kind of like their experience growing up in the church being different from other people, and what that looked like...as you probably know, most of people's experience in the church is not a very positive thing in that aspect.

Similarly, despite clear examples of abortion stigma, there were also examples of supportive and affirming views on abortion and sexual and reproductive health, generally. One Black male Minister (P17) explained, "My personal views on abortion? Hmm...That's a decision that the individual and God should make." Several pastors were also open to the ideas of more comprehensive sex education and birth control in church settings. One White male Pastor (P11) explained,

For the most part, we'll use the word progressive, they're on the progressive scale. I mean, gay marriage - we changed our canons to allow for gay marriage. We're not against contraception. We are - we consider ourselves pro-choice. When we say it, we mean profamily, pro-child... and life doesn't end until a person dies, not by the hands of the state.

A Black female Youth Minister (P14) explained the need for more information-sharing and education from experts about "birth control, abortions, healthy habits to have if you are sexual...dating... dating abuse." She also emphasized the importance of "not just making it a one-time program, but something that can continue on and on."

Several participants noted political barriers to real solutions for abortion including contraception and addressing poverty. A White male Pastor (P04) noted there are resources available for contraception and sexuality education but a lack of political will that is tied to economic ideology,

Political forces that are anti-abortion...also do not want to spend the money to provide birth control to everyone. We have enough money we could provide birth control to every single human being capable of carrying a child in the United States of America. We can just do it if we want...But we don't because they also don't want to spend money on "poor people" or quote un-quote "people who are abusing the system"...I think we should be providing resources...like birth control and safe sex stuff.

Notably, even when distancing himself from "antiabortion" forces, this pastor does not affirm abortion but rather emphasizes means to prevent it. A Black male Pastor (P10) elaborated on that lack of political will—particularly among Republicans - to provide postpartum support for children and their parents:

I'm not a proponent of [abortion]-morally, I think it's wrong, but individually, I think that's a choice the mother makes...For instance... I don't think the Republican Party en masse is...right for life. They are anti-abortionists. Those are two different things. So if 
a mother knows she can't take care of that child, the Republicans are saying, bring the child here, but when the child gets here, they don't want to expend the monies necessary to take care of the child...Does she do well by bringing that child in? She has no means for the kind of support that's needed. She's ill-prepared for the situation.

Again, this pastor is being tolerant of abortion without being affirming of that choice as he explains he is personally opposed but recognizes the choice is up to the mother. One Black female Regional Minister (P05) explained that social issues like poverty more so than abortion and "homosexuality" are typically the focus of Black churches. She said,

Euro-American churches focused on the issue of abortion and homosexuality because they're more [inward looking], and how African American churches focused more on social issues because...one of the main purposes of the African-American church is to provide opportunity for wellness and holistic, a sense of holistic being. That's why independent of what the position of the Black church is on abortion and homosexuality, they're like, 'We ain't dealing with that. We got people who need jobs. We got people who need to deal with health disparity and treatment options. We got people who need to go to school. We've got people who need to know Jesus.'

This was also reflected in White and Black participants' responses to questions about the sexual and reproductive health needs and priorities of their congregations. Across all religious leaders interviewed, the most common response was some version of "I don't know" or "I haven't thought about it." One Black male Senior Pastor (P13) explained, "In 98 percent of churches, that's not a conversation." Other answers did vary by congregations' age demographics and racial/ethnic composition. Among those who provided a different answer, Historically Black Protestant leaders most often identified infertility, access to prenatal care, unplanned and adolescent pregnancy, single motherhood challenges, and social determinants of health (access to health care, poverty, access to healthy food) as the sexual and reproductive health needs and priorities of their church community. Notably, several Black faith leaders noted other health concerns-not sexual or reproductive health - as their priority including hypertension, diet, and mental health. In contrast, White Mainline Protestant leaders (who did not say "none" or that they do not condone talking about it) most often identified mission work or concern for other disadvantaged groups (e.g., menstrual products for the homeless, child maltreatment on the Southern border), infertility (albeit less frequently than Black participants), unplanned and adolescent pregnancy and "promiscuity," pornography, family formation, and sexuality or outlooks on sex. Only one White participant, a lay leader at a United Methodist Church, identified basic needs of the congregation (homelessness and access to healthy food and healthcare) as the priority.

\section{Subtheme: Common Strategies for Building Supportive Abortion and LGBTQ Norms}

Lastly, religious leaders described effective strategies for shifting church-based norms on abortion and LGBTQ people toward support, empathy, and love. Several leaders described de-stigmatization of both abortion and LGBTQ relationships happening through narrative sharing, open conversation, personal relationships, and personal experiences with the stigmatized groups or stigmatizing events. One White male lay leader (P20) explained,

I came out when I was 15 . I'm 43 ...it's pretty okay to ask me whatever you need to ask me...there's so many people in our congregation who have been able to share their story... have been able to use the pulpit as a way to tell their stories, you know? And I think it takes stigma away from things whenever you allow an open pulpit like that... I think it's so important to hear their stories... I know I've heard a story in our pulpit of someone who has tried to get pregnant and not been able to, time and time and time again... but I don't know that I've heard in our pulpit someone who's had an abortion.

Religious leaders also emphasized the need for compassionate "open space" for "defusing myths and dislodging untruth" of religion and the whole-person approach to "people-centered public issues." A Black female youth minister (P14) expanded on the idea of open, loving spaces:

If it's coming from a place of love, then people will accept it more... So just really being open....individuals being transparent about situations they may have dealt with or situations they may have encountered, and being open to receive more information. So being open both ways.

\section{Discussion}

While there are important linkages between abortion stigma and stigma against gender and sexual minorities in Southern religious communities, the results show there is a wide diversity of views including support for abortion and LGBTQ inclusivity, which cannot be ignored when developing faith-based sexual and reproductive health programs. In this sample of White and Black Protestant religious leaders in Georgia, many described and/or endorsed faith-based 
stigma against abortion and LGBTQ identities and behaviors. Among those religious leaders who condemned abortion and/or LGBTQ people, participants referenced similar paradigms of sexual morality and rigid expectations of a cisgender, heterosexual binary. Religious scholars have previously explained that Protestantism bases its theological and ethical perspectives about the primacy of heterosexuality on the notion of complementarity between a (cis-gender) woman and a (cis-gender) man (Blevins, 2005). Further, scholars have theorized that homophobia, heterosexism, and trans* oppression are inextricably linked to sexism and the patriarchy (Catalano \& Griffin, 2016) through social expectations of hetero-normativity, masculinity, femininity, and repronormativity (compulsory reproduction of cis-gender women with cis-gender men within marriage and a nuclear family structure) (Franke, 2001). Therefore, public health professionals will be unlikely to disrupt abortion stigma without also addressing broader stigma against non-normative sexuality and gender identities and expressions.

Although there is substantial homophobia and abortion stigma within many religious spaces, these data show there are also powerful examples of faith communities that include, affirm, and uplift LGBTQ individuals and-to a lesser extent-people who have abortions. Perhaps the clearest example of this was the call from several White and Black religious leaders for evidence-based, comprehensive sexuality education in church settings for young people and adults that includes abortion, contraception, and LGBTQ topics. This echoes research on church-based HIV programming with young Black gay and bisexual men, who have also called for "sex positive education" about HIV, birth control, correct condom use, and healthy relationship techniques as well as creating safe spaces for open discussion about sexual health (Powell et al., 2016, p. 208). At the same time, our study would suggest sexual and reproductive health needs to be addressed comprehensively to include unintended pregnancy, abortion, and LGBTQ health; to date, the few evidence-based and faith-based sexual and reproductive health interventions have focused on HIV/ AIDS. Notably, while many participants endorsed gay rights and upheld LGBTQ identity and behavior as moral none explicitly upheld abortion as a moral choice. While some progressive faith leaders and religious scholars frame abortion as a moral choice (Frohwirth et al., 2018; Peters, 2018), our participants who accepted abortion typically described personal opposition to abortion but found tolerance for it, then called for focus on preventing abortion through contraception, sexuality education, and anti-poverty initiatives. Previous research from this study similarly documented how religious leaders did not condone abortion but were willing to provide loving, supportive pastoral care to congregants trying to make that decision (Dozier et al., 2020).
Public health professionals need to apply a culturally humble, assets-based (not deficits-based) framework when working with faith communities on sexual and reproductive health topics (Cutts \& Gunderson, 2018). Religious practitioners and public health scholars including Gary Gunderson and Teresa Cutts have developed and promoted a "strengths of congregations" framework and the idea of "religious health assets"(Cutts \& Gunderson, 2018). Both approaches require a participatory and strengths-based approach to collaboration between public health and religious sectors, rooted in the eight foundational strengths of all congregations: "the ability to accompany, convene, connect, tell stories, give sanctuary, bless, pray and endure" (Cutts \& Gunderson, 2018). Such models have been successfully applied in partnership with the Interfaith Health Program at Emory University to address HIV/ AIDS in South Africa as well as mental and chronic illness in Tennessee and North Carolina (Cutts \& Gunderson, 2018).

The study participants highlighted effective abortion and LGBTQ de-stigmatization strategies to promote holistic wellbeing including personal connection, story-sharing, compassion-building, (re)education, and buy-in from leadership. Researchers with the F.A.I.T.H.H. (Faith-based Antistigma Initiative Towards Healing HIV/AIDS) program in Alabama's Black faith communities similarly emphasize the importance of stigma-reduction frameworks and approaches that include accurate information, community empowerment, direct/indirect contact with people living with HIV, and collective social action (Bradley et al., 2018). Two rare examples of evidence- and faith-based approaches for abortion and LGBTQ de-stigmatization are the "Faith and Advocacy" training for clergy, advocates, and people interested in working with faith communities and the "Vacation Body School" by SisterReach, a Black-led reproductive justice organization in Memphis, Tennessee (SisterReach, 2020). Developed and delivered in collaboration with religious and public health leaders, the workshops cover Womanist theology centered education on human rights, reproductive access in correlation with the ministry of Jesus; sexual and reproductive health topics including unintended pregnancy, abortion, healthcare access, and story-telling that are connected to Christian scripture and values. These tactics are more persuasive and effective than traditional public health messaging precisely because they are framed in religious language and aligned with religious principles like love, justice, and mercy (Cutts \& Gunderson, 2018). Faith-based reproductive justice training is also intersectional, meaning it tends not only to issues of gender-based oppression, but also racial/ ethnic, economic, and LGBTQ oppression. However, funding and staffing shortages-perhaps, in part, because of the stigmatized topic-limit the reach of interventions such as "Faith and Advocacy" or "Vacation Body School" to only a handful of congregations monthly. 
Such intersectional approaches are especially needed when working with diverse faith communities that are facing intersectional stigma related to abortion, sexuality, race/ ethnicity, poverty, or otherwise. This was highlighted by the study participant who explained Black churches are less focused on homosexuality and abortion, because they are addressing more urgent social issues such as poverty, lack of education, and barriers to health equity. This was also reflected in all 20 religious leaders' description of sexual and reproductive health priorities in their congregations. While Black leaders emphasized their priority is addressing health disparities and social determinants of health in their own community, White leaders emphasized missionary work in and concern for other less privileged communities. In their study with Black sexual minority men in Baltimore, White and colleagues (White et al., 2019) found their participants typically preferred traditional Black churches over LGBTQaffirming churches in part because "all churches... are driven by the social and political agenda of the church membership and leadership" including anti-homophobia efforts. Racial differences in abortion experiences and attitudes were also noted by Black participants in the study, who emphasized that while they might personally disagree with abortion, it is a multi-factorial decision up to the individual, their God, and their ability to raise a child. Previous nationally representative studies similarly suggest that Black Americans are less likely to report perceived abortion stigma, regardless of their religious affiliation (Shellenberg \& Tsui, 2012). In a 2015 article, Cherisse Scott, founder and C.E.O. of SisterReach, explained how anti-abortion billboards in Atlanta and Memphis guilt Black people about their reproductive health decisions with emotionally laden and inaccurate information, for example by calling Black babies an "endangered species" as a result of abortion or "Dad's Princess" with a "heartbeat at 18 days." Such campaigns, created by White-led, Minneapolis-based organization Pro-Life Across America, not only erase actual reproductive injustices against Black and other indigenous people of color in the USA that often perpetuate the need for abortions, but also the social conditions, including racialized poverty, that drive some women of color to abortion (Davis, 2003; Roberts, 1997; Ross \& Solinger, 2017; Schoen, 2005; Scott, 2015). In fact, as Scott has explained, $80 \%$ of Black Americans-just as we heard from several of the Black religious leaders- "believe abortion should remain legal regardless of their personal feelings" (Scott, 2015).

Religious leaders and groups have led the charges in response to dominant institutional and public policy that reflect intersectional sexuality and abortion stigma. For example, Just Texas, "a grassroots movement of progressive people of faith and faith leaders from diverse religious traditions to speak publicly and politically in support of reproductive freedom and LGBTQ equality for all Texans" provides clear example of multilevel social policy action (Just Texas, 2021a). At the institutional level, Just Texas publicly declares willing religious affiliates as "reproductive freedom congregations," which affirm principles of freedom from reproductive stigma and discrimination (Just Texas, 2021a). At the state and federal policy level, Just Texas has released statements about court decisions such as June Medical Services v. Russo and local ordinances, with the expressed intention to counteract exclusionary and discriminatory narratives often encoded into law, fueled by conservative religious political power (Quinn, 2019; Just Texas, 2020, 2021b; Texas Freedom Network, 2019). Taken together, the results and other existing evidence provide counterexamples of abortion stigma and homophobia that challenge commonly-held notions of churches-particularly Black churches-as homogenous, static, and conservative.

The current study has a number of strengths and limitations. While the interviews with faith leaders in Georgia deepen understanding of these topics by illuminating conceptual and practical linkages between reproductive stigma and gender/sexual minority stigma, the purposive sample is not intended to be generalized to the larger population of religious leaders in the USA. In particular, the sample excludes non-Protestant churches as well as explicitly Evangelical churches, although the researchers notably interviewed Southern Baptist and Pentecostal religious leaders. Notably, other religious leaders were contacted but declined to participate. While those individuals did not vary by key demographics the team was tracking (ex: race/ethnicity, denomination), it is possible those leaders hold more negative views on abortion and related topics, so did not want to participate. Moreover, this sample of religious leaders-like the larger population of religious leaders in the USA-is predominantly male. Our results, therefore, might be limited in their ability to explore sexuality-based stigma among female clergy. However, among the four female clergy interviewed, we noted a range of diverse opinions on abortion and LGBTQ topics that were very similar to their male counterparts. This study also excludes congregation members themselves, but congregant interviews are ongoing and will be the focus of the next phase of research. Ultimately, this current study with Southern faith leaders provides rich and relevant context, identifies mechanisms of stigma, and suggests potential avenues for de-stigmatization.

\section{Conclusion}

This study enriches the current understanding of reproductive and sexual stigma in Southern Protestant faith communities as well as resilience and resistance to that stigma. The White and Black Protestant faith leaders the researchers interviewed from Georgia have described both phenomena 
as inherently linked by traditional cisgender roles and sexual purity norms. At the same time, faith leaders shared poignant examples of LGBTQ reconciliation and affirmation, as well as empathy, understanding, and support for people who have unintended pregnancies and abortions. The study participants emphasized how political barriers including economic ideology and partisanship make it difficult to address fundamental social issues like poverty, particularly in White churches that have not historically addressed social injustice. This experience highlights the need for mutually trusting and equitable partnerships between public health and religious leaders, with public health professionals operating from culturally humble, assets-based, and intersectional frameworks.

Acknowledgements This research was funded by an Anonymous Foundation. This work was also made possible through the support of Collaborative for Gender and Reproductive Equity, a sponsored project of Rockefeller Philanthropy Advisors. We would like to thank Indya Hairston for her contributions to data collection and coding. Further, we would like to thank the other members of the EnFaith Advisory Committee: Rev. Kimberly Jackson, Latishia James, Rob Keithan, Dr. Rebecca Todd Peters, and Charity Woods.

Funding This research was funded by an Anonymous Foundation and the Collaborative for Gender and Reproductive Equity, a sponsored project of Rockefeller Philanthropy Advisors.

Availability of Data and Materials Because of the sensitive nature of the qualitative data and the small community from which these data were collected, our dataset is not openly available to the public. Any inquiries about working with this dataset can be sent to the Corresponding Author.

\section{Declarations}

Conflict of Interest The authors declare no conflict of interest.

Open Access This article is licensed under a Creative Commons Attribution 4.0 International License, which permits use, sharing, adaptation, distribution and reproduction in any medium or format, as long as you give appropriate credit to the original author(s) and the source, provide a link to the Creative Commons licence, and indicate if changes were made. The images or other third party material in this article are included in the article's Creative Commons licence, unless indicated otherwise in a credit line to the material. If material is not included in the article's Creative Commons licence and your intended use is not permitted by statutory regulation or exceeds the permitted use, you will need to obtain permission directly from the copyright holder. To view a copy of this licence, visit http://creativecommons.org/licenses/by/4.0/.

\section{References}

Association of Religion Data Archives. (2010). Metro-area membership report. Quality Data on Religion. http://www.thearda.com/ RCMS2010/selectCountyA.asp

Blevins, J. (2005). Broadening the family of god: Debating same-sex marriage and queer families in America. Theology \& Sexuality, 12(1), 63-80. https://doi.org/10.1177/1355835805057787
Blevins, J. (2018). To transfer the empire of the world: Christianity's role in United States global health and development policy. Routledge.

Bradley, E. L. P., Sutton, M. Y., Cooks, E., Washington-Ball, B., Gaul, Z., Gaskins, S., \& Payne-Foster, P. (2018). Developing FAITHH: Methods to develop a faith-based HIV stigma-reduction intervention in the rural south. Health Promotion Practice, 19(5), 730-740. https://doi.org/10.1177/1524839917754044

Catalano, D. C., \& Griffin, P. (2016). Sexism, heterosexism, and trans* oppression. In An integrated perspective. In Teaching for Diversity and Social Justice (pp. 201-230).

Cockrill, K., \& Nack, A. (2013). I'm not that type of person: Managing the stigma of having an abortion. Deviant Behavior, 34(12), 973-990. https://doi.org/10.1080/01639625.2013.800423

Cockrill, K., Upadhyay, U. D., Turan, J., \& Greene Foster, D. (2013). The stigma of having an abortion: Development of a scale and characteristics of women experiencing abortion stigma. Perspectives on Sexual and Reproductive Health, 45(2), 79-88. https:// doi.org/10.1363/4507913

Crenshaw, K. (1989). Demarginalizing the Intersection of race and sex: A Black feminist critique of antidiscrimination doctrine, feminist theory and antiracist politics. University of Chicago Legal Forum, 139-169.

Cutts, T. F., \& Gunderson, G. R. (2018). Implications for public health systems and clinical practitioners: Strengths of congregations, religious health assets and leading causes of life. In D. Oman (Ed.), Why religion and spirituality matter for public health. Springer International Publishing. https://doi.org/10.1007/ 978-3-319-73966-3

Davis, A. (2003). Racism, birth control, and reproductive rights. In Feminist Postcolonial Theory: A reader (pp. 353-367).

Dedoose. (2018). [8.0.35]. SocioCultural Research Consultants, LLC. https://www.dedoose.com/

Dillon, M., \& Savage, S. (2006). Values and religion in rural America: Attitudes toward abortion and same-sex relations. https://scholars. unh.edu/carsey/12

Dozier, J., Hennick, M., Mosley, E. A., Narasimhan, S., Pringle, J., Clarke, L., James-Portis, L., Keithan, R., Hall, K. S., \& Rice, W. S. (2020). Abortion attitudes, religious and moral beliefs, and pastoral care among Protestant religious leaders in Georgia. PLoS One, 15(7). https://doi.org/10.1371/journal. pone. 0235971

Earnshaw, V. A., \& Kalichman, S. C. (2013). Stigma experienced by people living with HIV/AIDS. In P. Liamputtong (Ed.), Stigma, discrimination and living with HIV/AID (pp. 23-38). Springer Netherlands. https://doi.org/10.1007/978-94-007-6324-1_2

Flay, B. R., Snyder, F. J., \& Petraitis, J. (2009). The theory of triadic influence. In Emerging Theories in Health Promotion Practice and Research (2nd ed.). Jossey-Bass.

Franke, K. M. (2001). Theorizing yes: An essay on feminism, law, and desire. Columbia Law Review, 101(1), 181-208.

Frohwirth, L., Coleman, M., \& Moore, A. M. (2018). Managing religion and morality within the abortion experience: Qualitative interviews with women obtaining abortions in the U.S. World Medical \& Health Policy, 10(4), 381-400. https://doi.org/10.1002/ wmh3.289

Gaydos, L. M., Smith, A., Hogue, C. J. R., \& Blevins, J. (2010). An emerging field in religion and reproductive health. Journal of Religion and Health, 49(4), 473-484. https://doi.org/10.1007/ s10943-010-9323-1

Georgia Department of Public Health. (2020). Induced termination of pregnancy mapping tool [Data Warehouse]. Online Analytical Statistical Information System. https://oasis.state.ga.us/gis/ TrendableMaps/agsITOPTrend.aspx

Goffman, E. (1963). Stigma: Notes on the management of spoiled identity. Simon \& Schuster. 
Goodman, S. V. (2017). Spirituality, healing and the whole person: Reconciling faith in the transgender community. 17, 10.

Graham, J., Haidt, J., Koleva, S., Motyl, M., Iyer, R., Wojcik, S. P., \& Ditto, P. H. (2013). Moral foundations theory: The pragmatic validity of moral pluralism. Adances in Experimental Social Psychology, 47, 55-130.

Graham, L. F. (2014). Navigating community institutions: Black transgender women's experiences in schools, the criminal justice system, and churches. Sexuality Research and Social Policy, 11(4), 274-287. https://doi.org/10.1007/s13178-014-0144-y

Griffith, D. M., Campbell, B., Allen, J. O., Robinson, K. J., \& Stewart, S. K. (2010). YOUR blessed health: An HIV-prevention program bridging faith and public health communities. Public Health Reports, 125(1_suppl), 4-11. https://doi.org/10.1177/00333549101250S102

Guttmacher Institute. (2020). State sexuality education policy in 2020 (State Policies in Brief). Guttmacher Institute.

Harris, L. H. (2012). Stigma and abortion complications in the United States. Obstetrics \& Gynecology, 120(6), 1472-1474. https://doi.org/10.1097/AOG.0b013e3182723d82

Hasenbush, A., Flores, A. R., Kastanis, A., Sears, B., \& Gates, G. J. (2014). The LGBT divide: A Data portrait of LGBT people in the Midwestern, Mountain \& Southern States (p. 42). The Williams Institute.

Hatzenbuehler, M. L., Phelan, J. C., \& Link, B. G. (2013). Stigma as a fundamental cause of population health inequalities. American Journal of Public Health, 103(5), 813-821. https://doi.org/10. 2105/AJPH.2012.301069

Herek, G. M., Chopp, R., \& Strohl, D. (2007). Sexual stigma: Putting sexual minority health issues in Context. In I. H. Meyer \& M. E. Northridge (Eds.), The Health of Sexual Minorities (pp. 171-208). Springer US. https://doi.org/10.1007/ 978-0-387-31334-4_8

Jeffries, W. L., Dodge, B., \& Sandfort, T. G. M. (2008). Religion and spirituality among bisexual Black men in the USA. Culture, Health \& Sexuality, 10(5), 463-477. https://doi.org/10.1080/ 13691050701877526

Jelen, T. G. (2015). Gender role beliefs and attitudes toward abortion: A cross-national exploration. Journal of Research in Gender Studies, 5,11 .

Jelen, T. G., \& Wilcox, C. (2003). Causes and consequences of public attitudes toward abortion: A review and research agenda. Political Research Quarterly, 56(4), 489-500. https://doi.org/10.1177/ 106591290305600410

Jones, R. K., Witwer, E., \& Jerman, J. (2019). Abortion incidence and service availability in the United States, 2017. Guttmacher Institute. doi, 10(1363/2019), 30760.

Just Texas. (2020). Just Texas press statement on the U.S. supreme court's June medical services v. Russo decision on Louisiana's anti-abortion law. Texas Freedom Network. https://tfn.org/justtexas-press-statement-on-the-u-s-supreme-courts-june-medicalservices-v-russo-decision-on-louisianas-anti-abortion-law/

Just Texas. (2021a). Just Texas: Faith voices for justice. https://justtx. org/

Just Texas. (2021b). Shaping policy. Texas Freedom Network. https:// justtx.org/about/\#policy

Krawczyk, C. S., Funkhouser, E., Kilby, J. M., \& Vermund, S. H. (2006). Delayed access to HIV diagnosis and care: Special concerns for the Southern United States. AIDS Care, 18(sup1), 35-44. https://doi.org/10.1080/09540120600839280

Kumar, A., Hessini, L., \& Mitchell, E. M. H. (2009). Conceptualising abortion stigma. Culture, Health \& Sexuality, 11(6), 625-639. https://doi.org/10.1080/13691050902842741

Lindley, L. L., Coleman, J. D., Gaddist, B. W., \& White, J. (2010). Informing faith-based HIV/AIDS interventions: HIV-related knowledge and stigmatizing attitudes at project F.A.I.T.H. churches in South Carolina. Public Health Reports, 125(1_suppl), 12-20. https://doi.org/10.1177/00333549101250S103

Link, B. G., \& Phelan, J. C. (2001). Conceptualizing stigma. Annual Review of Sociology, 27, 363-385.

Masci, D. (2018). American religious groups vary widely in their views of abortion (Abortion). Pew Research Center. https://www.pewresearch. org/fact-tank/2018/01/22/american-religious-groups-vary-widely-intheir-views-of-abortion/

Meyer, I. (1995). Minority stress and mental health in gay men. Journal of Health and Social Behavior, 36(1), 38-56.

Mosley, E. A., Anderson, B. A., Harris, L. H., Fleming, P. J., \& Schulz, A. J. (2019). Attitudes toward abortion, social welfare programs, and gender roles in the U.S. and South Africa. Critical Public Health, 1-16. https://doi.org/10.1080/09581596.2019.1601683

Movement Advanced Project. (2021). Equality maps: Healthcare laws and policies. https://www.lgbtmap.org/equality-maps/healthcare_ laws_and_policies

Mullings, L., \& Schulz, A. (2006). Intersectionality and health: An introduction. In Gender, race, class, and health: Intersectional approaches. Jossey-Bass.

Nash, E. (2019). State abortion policy landscape: From hostile to supportive. Guttmacher Institute. https://www.guttmacher.org/print/ article/2019/08/state-abortion-policy-landscape-hostile-supportive

National Abortion Federation. (2020). Find a provider. National Abortion Federation. https://prochoice.org/think-youre-pregnant/find-a-provider/

National Opinion Research Center. (2021). General social survey data explorer. NORC at University of Chicago. https://gssdataexplorer.norc.org/

Norris, A., Bessett, D., Steinberg, J. R., Kavanaugh, M. L., De Zordo, S., \& Becker, D. (2011). Abortion stigma: A reconceptualization of constituents, causes, and consequences. Women's Health Issues, 21(3), S49-S54. https://doi.org/10.1016/j.whi.2011.02.010

Päivänsalo, V. (2013). Tackling faith-based stigma in the context of HIV/ AIDS. In Chronicity, care and complexity. Inter-Disciplinary Press.

Peters, R. T. (2018). Trust women: A progressive christian argument for reproductive justice. Beacon Press.

Pew Research Center. (2019). Religious groups' official positions on same-sex marriage (Politics \& Policy). Pew Research Center. https:// www.pewresearch.org/politics/2019/12/17/5-gender-family-andmarriage-same-sex-marriage-and-religion/

Pew Research Center. (2020a). Belief in God by race/ethnicity (religious landscape study). Pew Research Center. https://www.pewforum. org/religious-landscape-study/compare/belief-in-god/by/racial-andethnic-composition/

Pew Research Center. (2020b). Party affiliation among adults in Georgia by race/ethnicity (2014) (Religious Landscape Study). Pew Research Center. https://www.pewforum.org/religious-landscapestudy/compare/party-affiliation/by/racial-and-ethnic-composition/ among/state/georgia/

Pingel, E. S., \& Bauermeister, J. A. (2018). Church hurt can be the worst hurt: Community stakeholder perceptions of the role of Black churches in HIV prevention among young Black gay and bisexual men. Culture, Health \& Sexuality, 20(2), 218-231. https://doi.org/10.1080/13691058.2017.1338756

Powell, T. W., Herbert, A., Ritchwood, T. D., \& Latkin, C. A. (2016). Let me help you help me: Church-based HIV prevention for young black men who have sex with men. AIDS Education and Prevention, 28(3), 202-215. https://doi.org/10.1521/aeap.2016.28.3.202

Quinn, D. (2019). Faith leaders speak out against abortion bans. Texas Freedom Network. https://tfn.org/faith-leaders-speak-abortion-bans/

Reif, S. S., Whetten, K., Wilson, E. R., McAllaster, C., Pence, B. W., Legrand, S., \& Gong, W. (2014). HIV/AIDS in the Southern USA: A disproportionate epidemic. AIDS Care, 26(3), 351-359. https:// doi.org/10.1080/09540121.2013.824535

Rice, W. S., Turan, B., Stringer, K. L., Helova, A., White, K., Cockrill, K., \& Turan, J. M. (2017). Norms and stigma regarding pregnancy decisions during an unintended pregnancy: Development and predictors of scales 
among young women in the U.S. South. PLoS One, 12(3), e0174210. https://doi.org/10.1371/journal.pone.0174210

Roberts, D. (1997). Killing the black body: Race, reproduction, and the meaning of liberty. Random House LLC.

Ross, L., \& Solinger, R. (2017). Reproductive justice: An introduction (Vol. 1). University of California Press.

Schoen, J. (2005). Choice \& coercion: Birth control, sterilization, and abortion in public health and welfare. University of North Carolina Press.

Scott, C. (2015). Exploiting the Black family: A divisive campaign of the anti-woman, pro-life movement. Rewire News. https://rewire.news/ article/2015/05/15/exploiting-black-family-divisive-campaign-antiwoman-pro-life-movement/

Shellenberg, K. M., \& Tsui, A. O. (2012). Correlates of perceived and internalized stigma among abortion patients in the USA: An exploration by race and Hispanic ethnicity. International Journal of Gynecology \& Obstetrics, 118, S152-S159. https://doi.org/10. 1016/S0020-7292(12)60015-0

SisterReach. (2020). Faith and advocacy: A program of sisterreach. SisterReach: What We Do. https://www.sisterreach.org/what-wedo.html

Smith, W., Turan, J. M., White, K., Stringer, K. L., Helova, A., Simpson, T., \& Cockrill, K. (2016). Social norms and stigma regarding unintended pregnancy and pregnancy decisions: A qualitative study of young women in alabama: social norms and stigma around pregnancy decisions. Perspectives on Sexual and Reproductive Health, 48(2), 73-81. https://doi.org/10.1363/48e9016
Szymanski, D. M., \& Carretta, R. F. (2020). Religious-based sexual stigma and psychological health: Roles of internalization, religious struggle, and religiosity. Journal of Homosexuality, 67(8), 1062-1080. https://doi.org/10.1080/00918369.2019.1601439

Texas Freedom Network. (2019). Joint press release: faith leaders in McAllen: Bless this Clinic. Texas Freedom Network. https://tfn. org/join-press-release-faith-leaders-mcallen-bless-clinic/

United States Census Bureau. (2020). Quick Facts. Quick Facts. https:// www.census.gov/quickfacts/fact/table/US/PST045219

Ward, G. (1998). The erotics of redemption-After Karl Barth. Theology and Sexuality, 8(5), 52-72.

White Hughto, J. M., Reisner, S. L., \& Pachankis, J. E. (2015). Transgender stigma and health: A critical review of stigma determinants, mechanisms, and interventions. Social Science \& Medicine, 147, 222-231. https://doi.org/10.1016/j.socscimed.2015.11. 010

White, J. J., Dangerfield, D. T., Donovan, E., Miller, D., \& Grieb, S. M. (2019). Exploring the role of LGBT-affirming churches in health promotion for Black sexual minority men. Culture, Health \& Sexuality, 1-16. https://doi.org/10.1080/13691058.2019.1666429

Woolever, C., Bruce, D., Kopacz, J., \& Smith-Williams, I. (2020). U.S. Congregational Life Survey Wave 2 2008/2009 Random Sample Leader Survey. Association of Religion Data Archives. http:// www.thearda.com/RCMS2010/selectCountyA.asp

Publisher's Note Springer Nature remains neutral with regard to jurisdictional claims in published maps and institutional affiliations. 